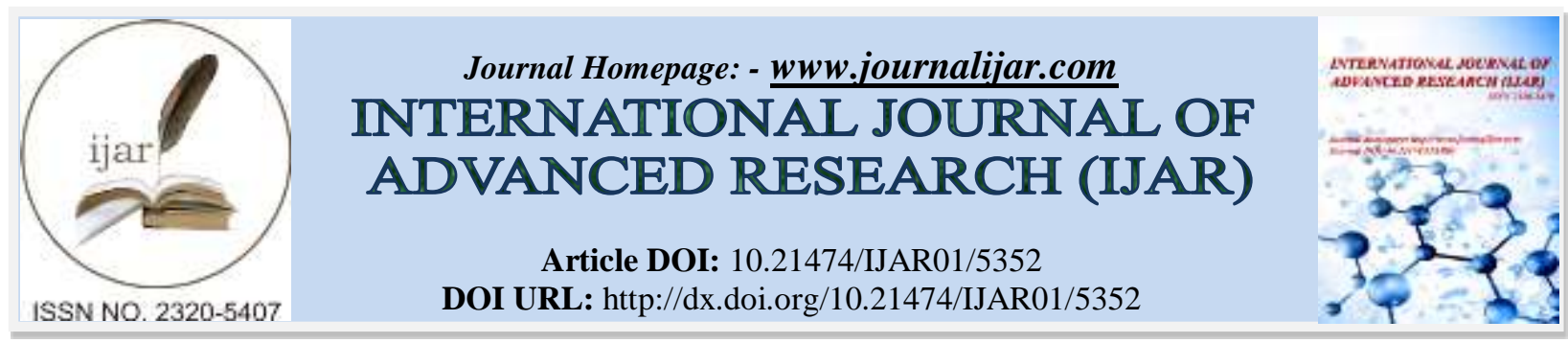

RESEARCH ARTICLE

\title{
STANDARDIZATION OF PROPAGATION THROUGH STEM CUTTINGS OF FIVE SALACIA SPECIES, IMPORTANT ANIDIABETIC MEDICINAL PLANTS OF WESTERN GHATS.
}

\author{
K. Muhammad Anaz ${ }^{1}$, N. Sasidharan ${ }^{2}$ and M. V Dilsha. \\ Kerala Forest Research Institute, Peechi, Thrissur- 680 653, Kerala, India.
}

\section{Manuscript Info}

Manuscript History

Received: 07 July 2017

Final Accepted: 09 August 2017

Published: September 2017

Key words:-

Salacia, propagation, gambleana, oblonga, malabarica.

\section{Abstract}

Studies on the standardizion of vegetative propagation protocols through stem cuttings with growth regulators for five species of Salacia L. viz S. brunoniana, S. malabarica, S. oblonga, S. gambleana and $S$. Fruticosa belonging to the family Celastraceae was carried out at Kerala Forest Research Institute, Peechi, Thrissur. Semi hard wood cuttings were treated with Indole Butyric Acid and Naphthalene Acetic Acid in different concentrations. Rooting response was measured after two weeks in the mist chamber. Variations were also observed in the establishment and root induction after five months of treatment according to the species and concentrations of Indole Butyric Acid. Among the treatments, cuttings treated with Indole Butyric Acid showed good results as far as rooting of the cuttings and establishment of rooted cuttings.

Copy Right, IJAR, 2017,. All rights reserved.

\section{Introduction:-}

Since the beginning of human civilization, medicinal plants have been used by mankind for their therapeutic value. It is estimated that about $80 \%$ of the world's inhabitants relying mainly on traditional medicines for their primary health care (Owolabi \& al., 2007). The genus Salacia L. comprises over 200 species distributed mostly in the tropical regions of south and south-east Asia, tropical Africa and Brazil of tropical America (Mabberly, 2008). Twenty one Salacia species are reported in India (Ramamurthy and Naithani, 2000); 7 species from the elsewhere Presidency of Madras (Gamble, 1918). Since then a few more species were described and at present there are 10 species in Kerala (Sasidharan, 2016). The International Diabetes Federation (IDF) predicts the growth of diabetic patients from 366 million in 2011 to 552 million in 2030 (Whiting \&al., 2011). Due to the shortage of effective drugs in modern medicines, people still depend on herbal formulations for diabetes. A group of tropical scandent shrubs known under the Sanskrit name 'Saptrangi' belonging to the genus Salacia is the forerunner in this group, which have a long history of use in the traditional medicine systems of India. In all the anti-diabetic herbal formulations, root of Salacia is a major ingredient. Salacia roots are also used in cases of inflammation, leucorrhoea, leprosy, skin diseases, amenorrhoea, dysmenorrhoea, wounds, ulcers, hyperhydrosis, hepatopathy, dyspepsia, flatulence, colic, spermatorrhoea etc. (Rao, 2007). Modern research has validated the efficacy of root bark of Salacia sp. against type II Diabets. The binomial Salacia reticulata, is the most widely referred name in biochemical and antidiabetic studies carried out on the genus in India and abroad.Recent study by Udayan \& Pradeep (2012) concluded that $S$. reticulata is not occurring in India and is restricted to Sri Lanka. Though, Salacia reticulata, $S$. chinensis and $S$. oblonga are often attributed as the source of Ponkoranti in trade, our investigations showed that roots of almost all species of Salacia are collected and marketed. It is very difficult to distinguish the species of Salacia based on the morphological characters of root. 
Considering the economic importance and accelerated exploitation as a drug plant form the wild, it is very essential to implement programs for the conservation and sustainable utilization of the valuable bio-resource. Cultivation is an effective alternative to conserve the species in the wild and to provide raw drugs to the herbal industry. Propagation through seed is an important method in plants as it carries the genotype of both parents. It has been established that seeds of several tropical plants are recalcitrant and do not withstand drying,thus, they are difficult to store for longer period (Ellis et. al, 1985). The seeds of Salacia are recalcitrant. For many plants, propagation through seed is not adequate because of low seed setting and low viability of seeds. Except $S$. chinensis, $S$. gambleana and $S$. fruticosa all have low fruit set. Apart from regeneration through seeds, propagation from vegetative parts such as stems, roots, rhizomes, bulbils or leaves is noticed in several plants. Propagules raised by vegetative methods retain their genetic constitution of the parent plants. In order to maintain the genotype, many horticultural plants are propagated largely through vegetative methods. Further, hybrid crop plants produced through breeding are propagated by vegetative methods either because of the lack of fruit setting or due to sterility of the hybrids. In forestry, vegetative propagation has been practiced to produce planting stock of the desired trees. Vegetative methods are adopted in the case of species having irregular fruiting, poor seed setting, low germination percentage, etc.

Grafting and layering are the common vegetative propagation methods adopted for tree species. These methods have been standardized for horticultural crops such as mango, cashew, rubber, etc. Micro propagation through tissue culture has also been standardized and protocols developed for spices and ornamental plants. The success rate of tissue culture of the tree species has been comparatively few (teak, bamboo, etc.). Propagation through rooted cuttings has been standardized and protocols developed for species such as Eucalyptus (Campinhos and Ikemori, 1980); Dipterocarpus (Srivastava \& Maggil, 1981); Gmelina arborea (Florido, 1978); Santalum album (Siuli \& al., 2014); Salacia fruticosa (Saumya \& al., 2014). Trials conducted on tree species (Amatya, 1982) indicate that optimum conditions vary with species and also depend on the age of the cuttings. Hence, standardization of growth regulating hormones, dosage and best season for induction of rooting need to be standardized. In the present study were carried out in five Salacia species to standardize the vegetative propagation through stem cuttings with growth regulators

\section{Materials and Methods:-}

Semi hard wood cuttings of different Salacia spp. were selected from natural forests as well as from the Medicinal plants Garden of the Institute. Hormones like Indole Acetic Acid (IAA), Indole Butyric Acid (IBA) and Naphthalene Acetic Acid (NAA) were first selected to standardize the for callus induction. Concentrations ranging 1000-6000ppm of IAA, IBA, NAA were prepared and applied on the cuttings. Among the treatments, cuttings treated with IBA showed good results. Therefore, further trials were carried out with IBA. For standardizing the optimum concentration of IBA, 1000ppm, 3000ppm, 4000ppm, 6000ppm, 7000ppm and 8000ppm were tried.

Twigs with two nodes were excised either at the node or internode with 2 to 4 leaves. The leaf blades were pruned more than half of their size with the help of a sharp scissors without causing any damage to the apical bud, so as to reduce the rate of transpiration. All the stem cuttings were treated with broad-spectrum systematic fungicide $1 \%$ Bavistin (Carbendazim 50\% WP) solution for $15 \mathrm{~min}$ as prophylactic treatment. After treatment with fungicide, the basal portion of the cutting was treated with various concentrations of hormones by dip and talc methods. A set of stem cuttings without any hormone treatment was maintained as control to compare the effect of hormones.

Applications of hormone through dip method and powder form were tried. IBA Concentrations such as 1000ppm, 3000ppm, 5000ppm and 6000ppm were used for S. brunoniana, S. oblonga, S. malabarica, S. fruticosa and S. gambleana. For the preparation of $20 \mathrm{ml}$ of $1000 \mathrm{ppm}$, to $30 \mathrm{mg}$ hormone ethyl alcohol was added drop by drop till the hormone dissolved in it and make up the solution to $20 \mathrm{ml}$. For other concentrations like 3000 (60 mg in $30 \mathrm{ml}$ ), $5000(100 \mathrm{mg}$ in $20 \mathrm{ml}), 6000(120 \mathrm{mg}$ in $20 \mathrm{ml})$, the same procedure was followed. The cuttings were dipped for 60 seconds before planted in root trainers.

In the powder form method, $1000 \mathrm{ppm}$ was prepared by adding $0.005 \mathrm{~g}$ hormone to $4.995 \mathrm{~g}$ talcum powder and mixed well using a Mikro-Dismembrator for 5 minutes. The same procedure was used for concentrations such as 3000ppm, 4000ppm and 6000ppm. Due to shortage of cuttings, S. beddomei and S.macrosperma were directly treated with concentrations of 5000ppm, $6000 \mathrm{ppm}$ respectively. The collection localities of Salacia spp. and 
different concentrations of IBA tried are provided in Table 1. There were three replications per treatment combination and each replication contained 10 cuttings.

Table 1:-Different concentrations of IBA in the rooting of cuttings of Salacia spp.

\begin{tabular}{|c|c|c|c|c|c|c|c|c|}
\hline \multirow[t]{2}{*}{ Species } & \multirow[t]{2}{*}{ Place of collection } & \multirow{2}{*}{$\begin{array}{l}\text { Type of } \\
\text { collection }\end{array}$} & \multirow[t]{2}{*}{ IBA treatments } & \multicolumn{5}{|c|}{ Number of replicas } \\
\hline & & & & $\mathrm{R} 1$ & $\mathrm{R} 2$ & R3 & $\mathrm{R} 4$ & $\mathrm{H}$ \\
\hline \multirow{4}{*}{ S.brunoniana } & \multirow{4}{*}{ Kulamav } & \multirow{4}{*}{ Semiwood } & 4000ppm & 10 & 10 & 10 & 10 & \\
\hline & & & $6000 \mathrm{ppm}$ & 10 & 10 & 10 & 10 & \\
\hline & & & $7000 \mathrm{ppm}$ & 10 & 10 & 10 & 10 & \\
\hline & & & 8000ppm & 10 & 10 & 10 & 10 & \\
\hline \multirow{4}{*}{ S.malabarica } & \multirow{4}{*}{ Kulathupuzha } & \multirow{4}{*}{ Semiwood } & $4000 \mathrm{ppm}$ & 10 & 10 & 10 & 10 & \\
\hline & & & $6000 \mathrm{ppm}$ & 10 & 10 & 10 & 10 & \\
\hline & & & $7000 \mathrm{ppm}$ & 10 & 10 & 10 & 10 & \\
\hline & & & $8000 \mathrm{ppm}$ & 10 & 10 & 10 & 10 & \\
\hline \multirow{4}{*}{ S.oblonga } & \multirow{4}{*}{ Peechi } & \multirow{4}{*}{ Semiwood } & 4000ppm & 10 & 10 & 10 & 10 & \\
\hline & & & 6000ppm & 10 & 10 & 10 & 10 & \\
\hline & & & 7000ppm & 10 & 10 & 10 & 10 & \\
\hline & & & $8000 \mathrm{ppm}$ & 10 & 10 & 10 & 10 & \\
\hline \multirow{4}{*}{ S.gambleana } & \multirow{4}{*}{ Vellanimala } & \multirow{4}{*}{ Semiwood } & 4000ppm & 10 & 10 & 10 & 10 & \\
\hline & & & $6000 \mathrm{ppm}$ & 10 & 10 & 10 & 10 & \\
\hline & & & 7000ppm & 10 & 10 & 10 & 10 & \\
\hline & & & $8000 \mathrm{ppm}$ & 10 & 10 & 10 & 10 & \\
\hline \multirow{4}{*}{ S. fruticosa } & \multirow{4}{*}{ KFRI, Peechi } & \multirow{4}{*}{ Semiwood } & 4000ppm & 10 & 10 & 10 & 10 & \\
\hline & & & $6000 \mathrm{ppm}$ & 10 & 10 & 10 & 10 & \\
\hline & & & $7000 \mathrm{ppm}$ & 10 & 10 & 10 & 10 & \\
\hline & & & $8000 \mathrm{ppm}$ & 10 & 10 & 10 & 10 & \\
\hline
\end{tabular}

All the treated stem cuttings were planted in $10 \mathrm{~cm}$ x $5 \mathrm{~cm}$ root trainers filled with vermiculite (supplied by Keltech Energies Ltd., Bangalore). The cuttings were kept under intermittent mist inside the mist chamber. The temperature inside the mist chamber was maintained between $30-40^{\circ} \mathrm{C}$ and the relative humidity between $80-90$ per cent. The number of days taken for initial sprouting was recorded and the cuttings showing symptoms of withering were removed. On confirming the cuttings for adequate rooting, the humidity and temperature were gradually reduced to avoid algal attack. Minimum irrigation was given so as to keep the rooting medium just moist. The established cuttings were potted in polythene bags filled with potting mixture and kept in minimum sunlight in the nursery of the institute.

\section{Stastical analysis:-}

Univariate analysis were done by ANOVA in SPSS, by taking growth hormone, concentration as independant variable and root induction and percentage of establishment as dependant variable.

\section{Results:-}

Root induction carried out in five species of Salacia (S. brunoniana, S. malabarica, S. oblonga, S. gambleana and S. fruticosa) using various concentrations of IBA (4000ppm, 6000ppm, 7000ppm and 8000ppm) gave different percentage of rooting. Variations were also observed in the establishment and root induction after five months of treatment according to the species and concentrations of IBA (Table $2 \&$ Figure 1)

In case of S. brunoniana the percentage of establishment varied from 15-35\% in different treatments. This species showed highest growth response (as far as the root induction was concerned) at the lowest concentration of IBA i.e., @ 4000ppm (3.5 \pm 1.29$)$ and less growth at $8000 \mathrm{ppm}(1.5 \pm 1.00)$. In the case of $S$. malabarica the percentage of establishment varied from $65-100 \%$. This species showed highest root induction at 7000ppm (10 \pm 0$)$ and less root induction at $6000 \mathrm{ppm}(6.5 \pm 3.4)$. S. oblonga also responded differently (20-70\%) at different concentrations of IBA, highest root induction was observed in $7000 \mathrm{ppm}(7 \pm 1.15)$ and lowest in $4000 \mathrm{ppm}(2 \pm 0.82)$. In the case of $S$. gambleana the establishment range was between 40-98\%. Highest root induction shown by 8000ppm (9.8 \pm 0.5$)$ and lowest was $6000 \mathrm{ppm}(4 \pm 0.82)$ of IBA. In the case of $S$. fruticosa the range of establishment was 50-55\%. Among the treatments, IBA 4000ppm showed (5 \pm 1.83$)$ lowest root induction and 7000ppm $(5.5 \pm 1.29)$ as well as 8000 ppm $(5.5 \pm 1.92)$ showed highest percent of root induction. We tried the same with $S$. chinensis. Both dip and powder 
method failed to induce rooting. The results show that there was an increase in the root induction when the concentration of the hormone increased except for $S$. brunoniana. All the others showed increase in root in induction when treated $7000 \mathrm{ppm}$ and $8000 \mathrm{ppm}$ respectively. A positive correlation can be seen in the root induction when the concentration of the hormone increased. Low concentration failed to induce callus. This might be due to inability of low concentration of the hormone to induce root in Salacia.

Table 2:- The rooting response of IBA and its concentrations, growth and establishment of five species of Salacia after five months of treatment.

\begin{tabular}{|c|c|c|c|c|c|}
\hline Species & $\begin{array}{ll}\text { Place of } \\
\text { collection }\end{array}$ & $\begin{array}{l}\text { Type of } \\
\text { cuttings }\end{array}$ & $\begin{array}{l}\text { IBA } \\
\text { treatments }\end{array}$ & $\begin{array}{l}\text { Root } \\
\text { induction }\end{array}$ & $\%$ of establishment \\
\hline \multirow{4}{*}{$\begin{array}{l}S . \\
\text { brunoniana }\end{array}$} & \multirow{4}{*}{ Kulamav } & \multirow{4}{*}{ Semiwood } & 4000ppm & $3.5 \pm 1.29$ & $35 \%$ \\
\hline & & & 6000ppm & $3.0 \pm 0.82$ & $30 \%$ \\
\hline & & & 7000ppm & $1.5 \pm 1.29$ & $15 \%$ \\
\hline & & & 8000ppm & $1.5 \pm 1.00$ & $15 \%$ \\
\hline \multirow{4}{*}{$\begin{array}{l}S . \\
\text { malabarica }\end{array}$} & \multirow{4}{*}{ Kulathupuzha } & \multirow{4}{*}{ Semiwood } & 4000ppm & $8.3 \pm 1.26$ & $83 \%$ \\
\hline & & & 6000ppm & $6.5 \pm 3.4$ & $65 \%$ \\
\hline & & & 7000ppm & $10 \pm 0$ & $100 \%$ \\
\hline & & & 8000ppm & $7.5 \pm 1.9$ & $75 \%$ \\
\hline \multirow{4}{*}{$\begin{array}{l}\text { S. } \\
\text { oblonga }\end{array}$} & \multirow{4}{*}{ Peechi } & \multirow{4}{*}{ Semiwood } & 4000ppm & $2 \pm 0.82$ & $20 \%$ \\
\hline & & & 6000ppm & $4.3 \pm 1.26$ & $43 \%$ \\
\hline & & & 7000ppm & $7 \pm 1.15$ & $70 \%$ \\
\hline & & & 8000ppm & $6 \pm 1.41$ & $60 \%$ \\
\hline \multirow{4}{*}{$\begin{array}{l}\text { S. } \\
\text { gambleana }\end{array}$} & \multirow{4}{*}{ Vellanimala } & \multirow{4}{*}{ Semiwood } & 4000ppm & $5.5 \pm 2.08$ & $55 \%$ \\
\hline & & & 6000ppm & $4 \pm 0.82$ & $40 \%$ \\
\hline & & & 7000ppm & $8.8 \pm 0.96$ & $88 \%$ \\
\hline & & & 8000ppm & $9.8 \pm 0.5$ & $98 \%$ \\
\hline \multirow{4}{*}{$\begin{array}{l}S . \\
\text { fruticosa }\end{array}$} & \multirow{4}{*}{ KFRI, Peechi } & \multirow{4}{*}{ Semiwood } & 4000ppm & $5 \pm 1.83$ & $50 \%$ \\
\hline & & & 6000ppm & $5.3 \pm 2.22$ & $53 \%$ \\
\hline & & & 7000ppm & $5.5 \pm 1.29$ & $55 \%$ \\
\hline & & & 8000ppm & $5.5 \pm 1.92$ & $55 \%$ \\
\hline
\end{tabular}

The survival of cuttings was evaluated. Except one cutting of S. brunoniana, all other cuttings survived. Flowering occurred for the cuttings of S. fruticosa, S. malabarica, S. chinensis and S. oblonga during the first year.

\section{Discussion:-}

The growth regulators and their concentration significantly affected the rooting of plants. The positive response of growth regulating substances such as NAA, IBA, and chemicals such as boric acid, coumarin etc. on rooting has been reported in earlier works (Sharma and Aier 1989; Zeng \& al., 2005). However, the root promoting effect varied with auxin concentrations and types of auxin. In an earlier study $S$. fruticosa cuttings treated with both IBA and NAA above $5000 \mathrm{mg} / \mathrm{l}$ failed to initiate rooting (Saumya \& al, 2014). However, in the present study the rooting response was more or less similar for the cuttings treated with IBA at concentrations 4000ppm, 6000ppm, 7000ppm and 8000ppm (Table 5). The high auxin application is reported to produce toxicity and NAA is more toxic than IBA (Zeng and Lu 1988). The superiority of IBA in rooting of cuttings might be because IBA being an auxin, generally has distinct advantage over NAA as it is slowly destroyed by the auxin destroying enzyme linked system (Pearse, 1948). 


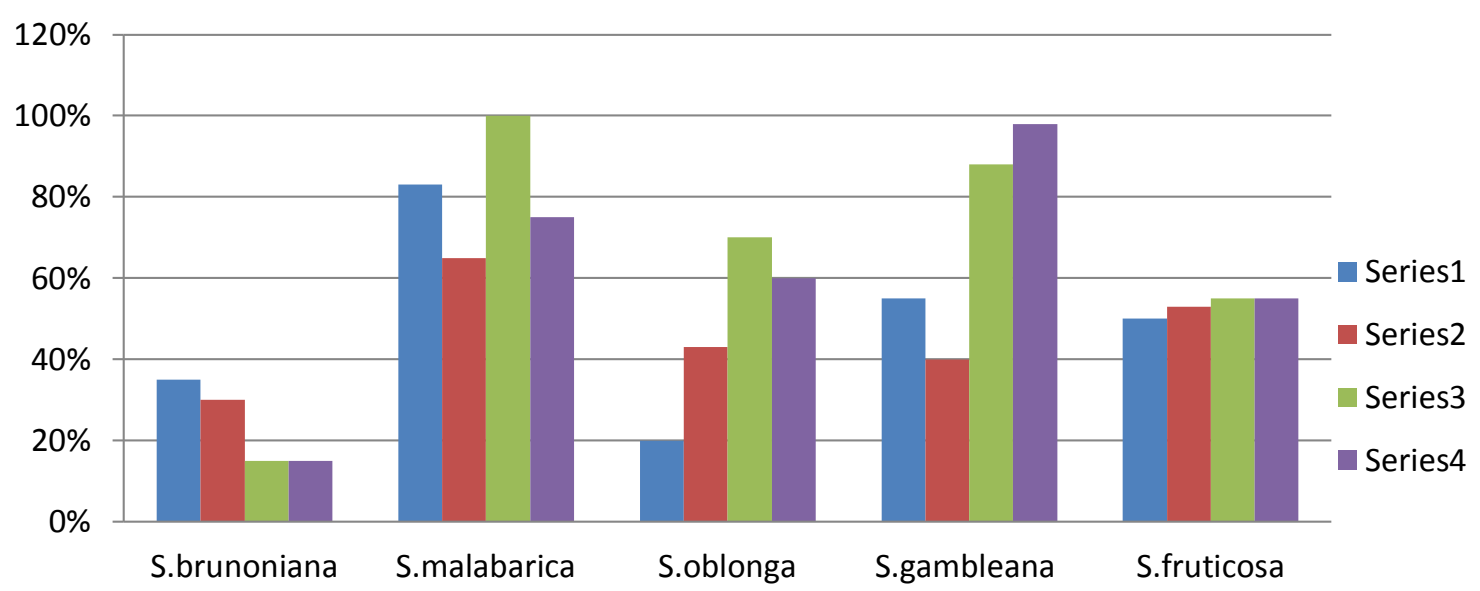

Figure 1. Percentage establishment of five spp of Salacia after treatment with IBA of different concentration in ppm.

\section{References:-}

1. Amatya, P.M., (1982): Simple techniques for propagation of stem cuttings in various plants. Nepal Forestry Technical Bulletin 7:23-29.

2. Campinhos, E. Jr. and Ikemori, Y.K. (1980): Mass production of Eucalyptus spp. by rooting cuttings. IUFRO Symposium and Workshop on Genetic improvement and productivity of Fast-growing tree species. 25-30th August, 1980. Aguasde Sao Pedro.

3. Ellis, R.H., T.D. Hong, and E.H. Roberts. (1985): Handbook of seed technology for genebanks. Volume II. Compendium of specific germination information and test recommendations. Intl. Board for Plant Genet. Resources, Rome.

4. Florido, L. V. (1978): Vegetative propagation by cuttings of Yemane (Gmelina arborea Roxb.) using growth hormones. Sylvatrop 3 (2): 115-122.

5. Gamble, J.S. (1918): Family Hippocrateaceae. The Flora of the Presidency of Madras. Adlard \& Son Ltd., London.

6. Mabberlay D.J. (2008): Plant-book-A Portable Dictionary of Plants, Their Classification and Uses. Cambridge University Press.

7. Nanda, K.K. (1970): Investigations on the use of auxins in vegetative reproduction of -forest plants. Final report of PL 480 Research Project, A7-FS-11 (FG In-255): 215p.

8. Owolabi, J., Omogbai, E.K.I.and Obasuyi, O. (2007): Antifungal and antibacterial activities of the ethanolic and aqueous extract of Kigelia africana (Bignoniaceae) stem bark. Afr. J. Biotechnol. 6(14): 882-885.

9. Pearse, H.L. (1948): Growth substances and their practical importance in horticulture. Technical Communication No. 20. Common Wealth Bureau of Horticulture and Pantation crops, East Malling, England.

10. Rao, M.S. (2007): Medicinal plant species with potential antidiabetic properties. J. Sci. Food Agri.87(5): 743750.

11. Rastogi, R. and Mehrotra, B.N. (1970-1979): Compendium of Indian Medicinal Plants. Vol.2. CDRI \& NISCOM, Lucknow, New Delhi.

12. Sasidharan, N. (2016): Taxonomy, Phytochemical Evaluation and Conservation of the Genus Salacia (Celastraceae) in South India. Final Technical Report. Kerala Forest Research Institute, Peechi, Thrissur.

13. Saumya, M.T., Jijesh, C.N., Hrideek, T.K. and Surendran, T. (2014): Standardization of propagation through cuttings in Salacia fruticosa Heyne ex Lawson: A Medicinal plant Endemic to Western Ghats. Inter. J. Agri. Environ. Biotech. 7 (3): 565-570.

14. Sharma, S.D. and Aier, N.B. (1989): Seasonal rooting behaviour of cuttings of plum cultivars as influenced by IBA treatments. Sci Hort 30:127-1344.

15. Srivastava, P.B.L. and Maggil, P. (1981): Vegetative propagation of some Dipterocarps by cuttings. Malaysian For. 44 (2 \& 3) 301-313. 
16. Batabyal, S., Dalal, T and Tah, J. (2014): Responses of some phyto-hormones for vegetative propagation of an ancient precious wood plant: Santalum album L. Biosci Discov, 5(2):170-174.

17. Udayan, P.S. and Pradeep, A.K., (2012): Notes on the occurrence of Salacia reticulata (Hippocrateaceae) in India. Acta Bot. Hung. 54(3-4):433-441.

18. Whiting, D.R., Guariguata, L., Weil, C. and Shaw, J. (2011): IDF diabetes atlas: global estimates of the prevalence of diabetes for 2011 and 2030. Diabetes Res. Clin. Pract. 94: 311-321.

19. Zeng, X. and Lu, Q.N (1988): Application of Plant Growth Regulators in Fruit Trees. 23 p. Agricultural Publishing House, Beijing.

20. Zeng, D.X., Yin, W.L., Wang, Y.H., Zhao, X.Q.and Wang, H.F (2005): Propagation with etiolated softwood cuttings of five dwarf cultivars of Chinese tree peony. Acta Hortic. Sin. 32: 725-728. 